\title{
Planning the Climate-Just City
}

Wendy Steele, Diana MacCallum, Jason Byrne \& Donna Houston

Correspondence: c/o Dr Wendy Steele, Urban Research Program, Griffith University, Nathan,

170 Kessels Road, Nathan Qld, 4111, Australia,w.steele@griffith.edu.au 


\title{
Planning the Climate-Just City
}

\begin{abstract}
Issues of urban equity have long been linked to urban planning. Yet in practice the quest for the 'just city', defined in terms of democracy, diversity, difference and sustainability, has proven to be highly problematic. Drawing on examples from the Australian urban context, we argue that the imperative of climate change adds urgency to the longstanding equity agenda of planning in cities. In our normative quest for the climate-just city we offer a conceptual and analytical framework for integrating the principles of climate justice and equity into urban planning thinking and practice.
\end{abstract}

KEY WORDS: Climate Justice, Equity, Cities, Climate change, Australia 
The essential interdependence between good environmental policy, good economic policy, and good social policy, will never be writ larger than in our response to climate change (Nicholson, 2007, p.2)

\section{Introduction}

Planning for justice, as Low and Gleeson (1998, p.1) note, “is no mere abstraction...but rather an activity with both material and discursive dimensions". Within the contemporary climate of economic, environmental and social change, what constitutes 'justice' is continually (and necessarily) being recast in relation to people, places and species. This is most acute in cities, where the majority of people now live. Yet despite the origins of urban planning as (at least in part) an instrument of social reform and inclusion, in practice planners have a poor record of achieving ideals of equity and justice (Winkler, 2009). Urban policies and plans have often served to compound rather than improve conditions of poverty, homelessness, access to basic services and ecological integrity, due to an institutional emphasis on growth and efficiency (Eisenschitz, 2008; Lovering \& Turkman, 2011; Miraftab, 2004; Peel, 1995).

As an intellectual and professional movement, urban planning has been intimately linked with the dominant regime of capital accumulation and distribution, and the implications of this for diverse urban communties (Harvey, 1989). Hall (2002, p.4) for example describes urban planning as "a response to the capitalist system and the problem of organizing production". For others the central question for planning praxis should be "what kind of role planning can play in developing the city and region within the constraints of a capitalist economy and a democratic system" (Campbell \& Fainstein, 2005, p.1). In the quest for the 'just' city the purpose of urban planning was considered to be (at least in part) an instrument of social reform, closely associated with strong reformist ideals around improving the human misery and squalor (Eisenschitz, 2008). 
In this paper we offer the framework of the climate-just city as a salient conceptual and analytical framework for taking the urban equity agenda forward within the context of climate change. The convergence of rapid urbanization and anthropogenic climate change, and the disproportionate effects of this on the urban poor and those most vulnerable have been emphasized extensively in both the academic literature and international policy reports (i.e. Bicknell et al. 2009; UN 2011). As the United Nations Global Report on Human Settlements Cities and Climate Change (2011) articulates, the more affluent in our society are less vulnerable, with the impacts of climate change felt most by the most marginalized groups, which include (but are not limited to) the urban poor, children, women and the elderly.

This raises significant urban justice implications. Climate change is a cultural/environmental crisis wherein the impacts are felt most by the most marginalised sectors of society (both human and non-human), and the response demands unprecedented redistribution efforts by those least affected and largely responsible (Adger at al., 2006). Society, economy and nature are all, simultaneously, mutually and constantly, reconfigured by the ways these connections are played out. The imperatives of democracy, social diversity, difference and equity that have underpinned notion of the 'just city' (Fainstein, 2010) must now take into account the complex links between human society and the natural environment. Yet these remain locked into processes that remain largely hardwired to an emphasis on a dry economic - not equitable -model of growth.

The aims of the paper therefore are threefold. The first is to track and extend conceptual thinking around 'the just city' to include a more overt focus on bridging the links between society and nature within the context of climate change and cities. Secondly, the paper extends this to the Australian context. As one of the world's driest continents and with a population perched precariously in coastal cities highly vulnerable to sea level rise, Australia is an urban hotspot at the frontline of climate change responses within the developed world 
(IPCC, 2007). The third aim is to build on these insights to offer a conceptual and analytical framework for highlighting eco-social justice considerations in the way urban planners respond to climate change. In our normative quest for the (climate-) just city the principles of climate justice and equity come first - not last -within planning policies and practices.

\section{Searching for the 'just city'}

The idea of the 'just city' is not new to urban planning. From its earliest conception, planning has sought to correct harms arising from living in cities and to advance a better quality of life for urban residents (Hall, 2002). In its formative days the discipline and profession worked to redress material expressions of inequality through spatial fixes and design interventions. But much of this period was focused on achieving 'design solutions' rather than on redressing the causes of socio-ecological problems. From the 1970s though, planning became much more concerned with the idea of 'social justice' and with instantiating normative ideals to redress or at least relieve the worst aspects of capitalism - those that produced poverty, homelessness, and immiseration. More recently planning has become concerned with ideals of justice that are embedded in the notion of sustainability - intergeneration equity, intra-generational equity and, arguably to a lesser extent, preserving biodiversity (inter-species equity) (Haughton, 1999; Kenny \& Meadowcroft, 2002; McManus, 2005). Arising within this context is Fainstein's conception of the 'just city'.

In this section of the paper we review these ideals of justice historically embedded within planning theory and practice to: (i) identify a basis for the climate-just city and (ii) begin to better understand why planning has thus far failed to substantively engage ideals of justice in planning for climate change. Four conceptions of justice that have permeated planning for the just city emerge: justice as access to goods or freedom from harms (equitable distribution); justice as redistribution of resources to those most in need (compensatory equity); demand distribution where the vocal special interest groups capture the lion's share of resources; and a 
'user pays' neoliberal version of justice (market-based distribution). Nonetheless, Bentham's notion of utility (the greatest good for the greatest number) has played a salient role in influencing planning thought around justice.

\section{Historical origins of the 'just city'}

Issues of urban equity have long been connected to urban planning. The reformist era of planning saw practitioners pursue better access to parks and playgrounds, improved sanitation and better quality housing for city-dwellers. Utopian visions of creating a better, more just and humane urban world found expression in the efforts of early urban pioneers such as Ebenezer Howard, Frank Lloyd Wright and Le Corbusier (Fishman, 1996). The garden cities of Ebenezer Howard for example were intended to redress not only limited access to nature, but also overcrowding, congestion, food insecurity, a lack of public transportation, childfriendly environments and better built environments for people with disabilities. These were all key agendas of contemporary planning (Parsons \& Schuyler, 2003). Through powerful economic, social and public health reform agendas planning-related knowledge and action converged around a larger purpose: the 'improvement' of urban areas and the plight of the poor (Hall, 2002).

The solution to these problems focused on improving the conditions of urban growth through utopian design and, at a more pragmatic level, through zoning and other regulatory development control mechanisms. However, as Sandercock (1990, p.213) observes, "this approach fails to come to terms with the real causes of the problem - the existence of poverty and the nature of the economic system". Thus, whilst the early social reformist concerns around public issues such as crime, overcrowding and ill-health remained, the sanctity of private property rights and values, as well as the dominance of technology, remained inviolate (just as they do today). 
These issues re-emerged dramatically in response to a new system of global capital accumulation and a growing awareness of an environmental crisis. The 1970s marked the beginning of a period of intense change in western capitalism that has had a deeply significant impact on the role and practice of Western planning for cities. The post-Fordist era brought with it quite a different agenda characterized by increased flexibility in terms of the processes of global production and consumption, the evolution of a new spatial order, the demise of the welfare state and the subsequent rise of a neoliberalized political regime (Jessop, 1995). Of particular note is that this straddles both political-economic and socio-cultural spheres thus broadening the socio-spatial scope, impact and implications for justice.

Harvey (1989) describes this as an urban era characterized by entirely new sectors of production, new ways of providing financial services, new markets and, above all, greatly intensified rates of commercial, technological, and organizational innovation (p.256). The rapid structural change in terms of capital, labour and the state was coupled with a greater emphasis on market orientation and a reduced role for the state. The emergence of a "new right' ideological framework spawned a raft of neo-liberal policies designed to "subordinate a wide array of possible social goals to more narrowly defined economic priorities" (Stilwell, 2000, p.14). Whilst the intensified rates of innovation under post-Fordist flexible accumulation are closely aligned with the increased speed and movement of economic growth, capital and territorial competitiveness within the context of globalisation. Caught in this increasingly uncertain, complex and shifting global context, a number of key changes affecting the capacity of urban planning to facilitate a progressive reform agenda included a transition to:

- Mobile capital and multinational corporations;

- Competitive and strategic territorial positioning;

- The global demand for resources; 
- Energy security and diversity;

- Changes to population structure as a result of people living longer; and

- Growth of cities and sub-regionalism as the scale for place-making.

(adapted from Koresawa \& Konvitz, 2001; Morphet et. al. 2007)

The implications for urban planning included: a shift away from the welfare state model; the pursuit of privatization; deregulation, downsizing and cost cutting underpinned by a strong politico-administrative emphasis on 'economic efficiencies'. This neoliberal style of planning rests on promoting rather than restricting entrepreneurial activity and development by streamlining planning decisions and seeking outcomes that largely serves to support marketled prosperity. For Harvey $(2005$, p3) this amounts to 'creative destruction', not only of institutional frameworks, but also of "welfare provisions, social relations, ways of life, attachments to the land, and matters of the heart". As Miraftab (2004) describes it, there is a tendency for increased processes of symbolic inclusion while the reality is material exclusion.

\section{The just city}

The 'just city' conceptualization (for example see Fainstein 1996, 2006, 2010; Marcuse et al. 2009) builds on an eclectic mix of philosophical thinking around questions of democracy, equity and diversity through the work of John Rawls (1999), Amartya Sen (1999), Martha Nussbaum (2000), Iris Marion Young (1990) and Henri Lefebvre (1996) among others. Though different in their values orientation these philosophical approaches conjoin to highlight issues of social fairness, equitable distribution of capital and resources. Irazabal (2009, p.558) observes that "urban elites frequently implement mechanisms that effectively prevent or control the spatial practices of 'others' that deviate from the ethos of a consumerist citizenship". Even urban policies and plans purposively designed to progress issues of justice have instead served to compound rather than improve conditions of poverty, homelessness, access to basic services and ecological integrity due to an emphasis on growth and efficiency 
within particular urban locales. Purcell (2002, p.101) describes this as "an argument for profoundly reworking both the social relations of capitalism and the current structure of liberal-democratic citizenship". As Gurstein and Vilches (2010) also make clear the "unjust city' abounds in western developed contexts as much as in developing country contexts. It is full of impediments (e.g. lack of adequate welfare rates, lack of affordable and secure housing, lack of childcare, impoverished social networks, and food insecurity). The biggest lesson of the neo-liberal formulation, they argue, is the need for active citizenship to achieve the just city. But they caution:

...we rewrite both activity and citizenry as exclusive domains of those who conform to standards of market production and consumption. In so doing, those who do not conform are forced to inhabit a residual city, one that operates beyond the official city and lacks the supports needed to thrive (p. 433).

Within the 'just city' literature the state, human activity and citizenry are the key foci for research, advocacy and analysis: the focus is almost exclusively on the dimensions of social justice, the dialectical role between citizen and state, and the injustices that occur for marginalised people within particular political, cultural and institutional environments - that is, human environments. But what of the interplay between human and natural and nonhuman environments; how do these relations define and shape dimensions of justice in the city?

\section{The 'environmentally-just' city}

Within the urban studies literature a largely parallel body of work to the 'just city' has emerged in a climate of environmental crisis and change. In an effort to expand the agenda of social justice, the burgeoning environmental justice movement has, since the 1980s, sought to redress socio-environmental problems and in particular problems traditionally ignored by mainstream environmental organizations and land use planners and policy makers (Byrne, 
2010; Harvey, 1996; Holifield et al. 2009). Such problems have included the disproportionate exposure of so-called minority groups and the poor to toxic waste dumps, polluting factories, industrial noise, hazardous biological waste, nuclear sites, and so called 'natural hazards' (i.e. flooding, landslides, storm-surge etc.) arising from capitalist processes of industrialization and land use (Cutter 2006). Environmental justice research has found that spatial planning has been often implicitly and sometimes explicitly involved in patterns of land use that have confined the most marginalised and vulnerable members of society to insalubrious houses, jobs, educational places and food landscapes (Pulido, 2000). At the heart of environmental justice struggles is contestation over access to and use of 'nature' in its various aspects (e.g. natural resources, clean water, healthy food etc).

More recently through the ecological justice movement this has been extended to include the rights of plants and animals to inhabit the city, to be free from harm and to satisfy their needs (Bell, 2010). Arising from diverse disciplines within urban studies, the ecological justice literature has sought to open up dialogues about our moral obligations to other species (Low \& Gleeson, 1998). While the literature within planning is still limited, proponents have begun to identify how planners might open and expand the domain of justice conceptions beyond humans to encompass animals, plants and even inanimate objects like rocks, rivers and oceans (Byrne, 2011). Baxter (2005, p.1) emphasizes that as "a result of human activities, many organisms on Earth face serious and worsening threats to their continued existence...this is a matter of concern because maintaining a healthy non-human environment affects the wellbeing of humans". The work of ecological justice considers how animals and plants might be accorded not just the right to live, but the right to flourish in cities. To reconfigure the cultural politics of 'nature as resource' or 'nature as agent' which has thus far dominated planning will be necessary in efforts to shift how planners engage with the non-human world (Wolch, 2002). 
These shifts hold particular resonance within the context of climate change in which our ideas about the just city must include not only questions of democracy, equity and economic distribution, but also questions of how human actions are impacting the non-human world. In the words of Hulme (2010):

Climate change is reminding us - in case we had imagined otherwise - that we are intimate co-workers with the non-human in the mutual shaping of our present and future worlds, rather than being lords of all we can see. Climate change is teaching us - in case we had hoped otherwise - that the future is irredeemably precarious and beyond all our efforts of prediction and control. And climate change is convincing us - in case we believed otherwise - that our identities and our interpretations of the world around us can never fully escape encounters with place and materiality (p.274).

Emerging understandings of urban and political ecology highlight cities as 'metabolic' systems in which practices of production and consumption continually alter both 'nature' and 'culture' (Swyngedouw \& Heynen 2003). Seeing these systems in their institutional contexts means critically engaging with the stories, ethics and practices shaping relations between humans and non-humans, a crucial task when faced with crises such as climate change (Waitt et al. 2006). For a growing number of urbanists, humanitarian justice scholars, environmental and ecological advocates, therefore, addressing the issues of what is being termed 'climate justice' has become the moral and ethical imperative of the times (Bell, 2010; Hulme, 2010).

\section{Climate justice and the city}

Justice and equity issues arise in the climate change context because of the high prospects for impacts on already vulnerable people and communities. In particular the capacity for climate change to compound existing vulnerabilities such as poverty, loss of biodiversity or degradation has been identified (O’Brien \& Liechenko, 2000). Climate justice acknowledges that in the face of potentially catastrophic climatic change, significant challenges have 
emerged that threaten the human world, the non-human world, sustainability and governance and decision-making more generally (Adger et. al. 2006). Barnett (2006, p.115) identifies five key aspects to understanding climate justice:

1. the responsibility for climate change is not equally distributed;

2. climate change will not affect all people equally with some people and groups more vulnerable;

3. this vulnerability is determined by political-economic processes that benefit some more than others;

4. climate change will compound under development because of the processes of disadvantage embedded within the (neo) liberal political-economic status quo; and

5. climate change policies may themselves create unfair outcomes by exacerbating, maintaining or ignoring existing and/ or future inequalities

Yet the emergent climate justice agenda has barely started to penetrate political discourses surrounding cities - particularly within the developed country context. In highly urbanized countries like Australia for example the uneven impacts of the climate crisis will be felt most in the largest cities, where most of the countries' human populations reside. Within urban planning hardwired to a staircase model of economic growth, making the necessary justice links between economic, social and ecological vulnerability remains on the margins. It is to this contested context that we now turn to situate climate justice in the city.

\section{Advance Australia fair}

Australia is a recognised global climate change hotspot (IPCC 2007). Nearly 70 percent of the population lives in the five largest cities located on the vulnerable coastline. The highly concentrated nature of the urban population in Australia coupled with the relatively fixed nature of much of the metropolitan built form serves to magnify climate related risks and vulnerabilities from extreme weather and natural disasters (i.e. sea-level rise, heat waves and drought). The vulnerability of Australian communities (both human and non-human) in one of 
the world's driest continents is at the frontline of climate change responses. Yet, in spite of the urgency with which such action is discursively promoted, climate justice remains a chronically "underdeveloped area of Australian thinking" (Garnaut, 2009, p.1). When climate justice discourses are present it is largely through the efforts of not-for-profit third sector groups (e.g. Friends of the Earth/FOE; Climate Action Network/CAN) rather than planners.

Urban planning in Australia has a long history of disengagement with issues of social justice and social equity concerns in the name of growth and efficiency (Sandercock, 1990). The tendency of urban planning to attend to matters of economic efficiency at the expense of social equity has marked and defined the Australian city form and context (Fincher \& Saunders, 2001). In the forward to the seminal Ideas for Australian Cities, Hugh Stretton observed that "there should be more equality in the use of cities, and in the way they distribute costs and benefits to their people" (1989, p.4). Whilst planning documents have long included aspirations about making a difference to the conditions of vulnerable communities, these have been largely rhetorical and generally failed to offer practical guidance for achieving increased equity and social justice (Peel, 1995). This has implications for addressing issues of climate equity and justice (Brotherhood of St. Lawrence, 2007).

In the 1990s Peel (1995) identified two themes related to urban planning, social disadvantage and justice in Australian cities. First, this involves recognition by planners of 'compounding inequality' which links long-term income and housing insecurity, lack of access to information and knowledge, and poverty into a vicious, self sustaining spiral. The second theme is around the need for those most affected by planning decisions to be able to be included and participate meaningfully in planning processes rather than be coerced. Peel (1995) also emphasized the power (and thus importance) of language in perpetuating urban disadvantage in Australia, where discourses around 'liveability' and 'lifestyle choices' dominate urban policy documents rather than 'poverty' and '(in)-justice'. The result was 
urban 'landscapes of despair' (see Dear \& Wolch, 1987) too often met with policy, planning and disciplinary silence and underwritten by economic marginalization and political invisibility. More recently Gleeson (2010) has argued for the need to subordinate the economy to human need and nature's balance; produce to sustain not to enrich; and foster values of care, repair and renewal not accumulation and consumption within the context of planning in climate change has been highlighted within the Australian context.

Since the 1980s Australian cities have experienced waves of micro-economic reform that have given enhanced status and influence to private interests in urban public policy and services. The outcome has been an increasing emphasis on: growth over sustainability; shareholders/stakeholders rather than citizens; velocity over quality; and economic efficiency over equity (Steele \& Gleeson, 2010). The seemingly entrenched divisions between economy, environment and equity is being replicated and, we argue, reinforced in the relatively recent engagement of urban planning with the challenges of climate change; where the emphasis remains to do more with less. The 'great risk shift' within Australian climate policy highlights a clear social gradient to climate policy and planning whereby the poor do not have ready access to climate change adaptation measures or schemes (Steele \& Gleeson, 2011). At the individual level, green consumption has been urged and households encouraged to make their housing secure and independent through water and energy improvements at the dwelling/site level. But change at this level is reliant on home-owners with the upfront financial capacity to build expensive eco-design houses or fully engage in the green initiative rebate schemes. At the collective level, urban policies continue to support and promote car dependent cities despite the rhetoric around achieving urban resilience through low carbon urban futures. The VAMPIRE index (Dodson and Sipe 2008, p.1) spatially mapped oil and mortgage vulnerability in Australian cities highlighting "a highly regressive pattern in which the 
impacts of higher fuel costs and increased interest rates fall on those with the least capacity to absorb them".

Within the Australian context current approaches to planning in climate change continue to be framed by an orientation to (financial, environmental and political) risk management, rather than to social, ecological or environmental justice (Byrne et al 2009). In the face of such marked social and ecological disparity work by Edwards et al. (2009) has highlighted a number of propositions that seek to support and promote a more equitable approach to climate change policy in Australia:

1. That scientific evidence and analysis confirms the need to take urgent action to prevent dangerous climate change - business and politics as usual is not an option;

2. Action to prevent climate change is a moral responsibility of all Australians and all sectors of society to develop just climate change responses which honour both intra and inter-generational equity;

3. The community has a vital role and responsibility in advocating urgent action and ensuring equitable approaches to mitigation and adaptation; and

4. Strategies to prevent greenhouse gas emissions and prevent dangerous climate change have strong social, ecological and environmental justice benefits.

Action on climate change is a planning imperative with potential benefits that extend across the full range of planning concerns. Renegotiating the balance between the 'hard head' and 'soft heart' of urban planning is required if we are to meet the challenges of climate change without exacerbating socio-economic polarisation and eco-social vulnerabilities. These struggles lie at the heart of what we term - the climate- just city. To this end new, practically oriented strategies and frameworks for knowledge production are required - ones that engage directly with the practices, stories and perspectives of those (human and other) actors that have been traditionally excluded from mainstream planning policies and practices. 


\section{The climate just city - towards a conceptual/analytical framework}

Within Australian cities a strong focus on issues of climate justice is not currently part of the urban policy or planning vernacular (MacCallum \& Byrne, 2009). The now manifest spectre of global warming has intensified the need to find creative, meaningful ways to address issues of climate justice as the relationship between humans, non-humans and nature is continually redefined. Yet the ontological and cultural dimensions of climate justice in cities remains chronically under-researched, in part because of a lack of analytical, conceptual and practical tools within urban studies and policy sciences for engaging with discourse and difference. Imagining a climate-just city will entail making better policy and planning connections between environmental, ecological and social concerns in order to create more equitable urban futures.

If we are to advance cities that are 'fair', then creative, multi-disciplinary approaches to justice and equity must be embedded deep within the collective consciousness and practices of disciplines such as urban planning. This entails wider recognition of the socio-spatial constraints that work to impede those already impoverished and suffering hardship within our society. More than this is the need to create an inclusive city based upon a different ordering of rights and different political-ecological practices and more engaged citizenship. A climate justice approach to cities challenges increasingly artificial dualisms deployed and reinforced in urban policy discourse around: nature-culture (ontology), present-future (epistemology) and global-local (geography) (Hulme, 2010).

As a first step, we offer the climate-just city as a scholarly lens for taking this agenda forward (see Figure 1 below). As an emergent conceptual and analytical framework, the emphasis is placed on the need to integrate the red and green dimensions of planning and climate change to include considerations of social justice (people), environmental justice (places) and ecological justice (non-humans). This framework might be described as 'cultural political 
ecology', drawing on recent insights from cultural political economy (Jessop \& Oosterlynck 2008; Ribera-Fumez 2009; Best \& Paterson 2009), urban ecology (Swyngedouw \& Heynen 2003; Keil 2003) and the cultural politics of nature (Clark 2010; Moore et al. 2003).

\section{-Insert figure 1 here -}

Our point of departure is the need to find and embed new techniques and methods for incorporating the principles of climate justice within existing mainstream urban governance processes, and to actively engage with alternative practices: to make more explicit and to put to work the synergistic links that shape and interpenetrate specific (in)justice practices and contexts (Houston, 2008). Our approach is underpinned by a need to better understand the situated practices of social/environmental exclusion and attachment as both political and semiotic, undergirded by political struggles over the making and ordering of rationalized and essentialised natures (Moore et al, 2003). By recognizing the contingency of the environmental imaginaries (cf Jessop's [2007] 'economic imaginaries') that shape urban policy, we can conceive of alternative ways of knowing climate change impacts and of addressing their inequitable material effects, which may in turn produce different policy and governance responses and ethical frameworks. Our theoretical framing also rejects the blunt distinctions between the natural and the social found in most climate change studies. Hard distinctions between the 'social' and the 'natural' have become blurred and increasingly meaningless (Demeritt 2001).

In adopting this eco-cultural-political approach however, we keep sight of the spatiality and materiality of urban injustice. Social exclusion studies show how urban vulnerabilities are created mostly through disinvestment in public infrastructure (Harvey 1996). The struggles surrounding exclusion, and the transfer of negative externalities from rich to poor, are realised as co-evolving spatio-material effects and public discourses. 
The climate-just city framework thus involves explicit attention to discourses, political processes, and social-ecological relations, as well as to the processes and outcomes of spatialmaterial distribution that work together to create a concrete imaginary of injustice - and how it might be corrected at Friedmann's (1987) interface between knowledge and action. Understanding how discourses of climate change are made and performed by different urban stakeholders offers important insights into how environmental problems shape urban governance, and how our policy responses can "hurt people" (Friends of the Earth 2010, p.1), by concentrating, entrenching and reproducing social, spatial and ecological inequality (Houston 2008).

The climate-just city approach emphasises engaging with those traditionally marginalised from the cultural context not only of urban climate change responses, but also of academic practice. In particular, there is a need to attend to the stories and visions of different actors in urban governance, and to identify practical pathways for action by paying attention to the relationship between texts (printed policy texts, built environments, spoken interaction, folklore), the discourses and practices that those texts realize, the political-economic circumstances in which those discourses arise, and the material effects that they have (Fairclough 2003).

If we accept that anthropogenic climate change is real - as the weight of reputable scientific evidence currently available suggests that we must - then we must also recognise that its impacts are likely to be felt unevenly, not only at a global scale, but also within cities. By incorporating diverse perspectives and adopting an open approach to their interpretation, the intention is for this framework and approach to enhance our understanding of limitations and potentials for climate justice at the urban scale. It is anticipated research using the climate-just city framework will involve: 
- Advancing understanding of how various urban governance actors (e.g. policy and decision makers, advocacy and service practitioners, and vulnerable people), imagine, conceptualise, and practice climate justice at various scales;

- Explaining how the institutional and cultural perspectives of these actors shape their imaginaries, issue-framing, and practice across multiple scales;

- Developing and applying innovative methods for putting climate justice into urban policy and community practice.

The climate-just city lens is thus designed to apply to contexts which have a cultural, historical and institutional fabric specific to particular places and spaces. The ground-truthing of the climate just city framework occurs within the 'situated stories and practices' involving activists, citizens and policy makers. The framework thus offers a new way of conceptualising and analysing the connections between discursive and material aspects of current climate change responses, for probing the policy silences and shadows that surround urban climate justice, and for imagining alternatives. But is this practical, or just another example of utopian thinking around the 'just city', this time with a climate change cast?

\section{Climate justice or just utopia?}

The need for a progressive political-ethical framework has been a recurring theme in the urban justice literature, particularly in the face of the 'creative destruction' posed by neoliberalism (Fainstein, 2010; Harvey, 2006; Low \& Gleeson, 1998). But as Purcell notes we are left without a good sense of how the just city might address the specific problems associated with urban neoliberalism and thus "a great gulf exists between the frequency with which the just city is mentioned and the depth with which it is explored" (2002, p. 101).

A number of authors have raised concerns about the disconnect in the just city literature between the moments of critique and constructive vision, between the 'is' and the 'ought', 
about what actually happens at the interface between knowledge, intention and action (see Campbell, 2010, Gunder 2011; Purcell, 2002). For Gunder (2011) just what constitutes the 'just city' and how planning can, and should, help to make this 'just city' occur is still frustratingly unclear, whilst for Heather Campbell (2010) the questions that really matter concern: 'whose justice are we referring to?' and 'what are the substantive meaning of situated justice?' Her argument is that urban research should not simply focus on the way policy-making in planning is subject to distortion (as is often the case), but rather should seek to critically unpack the different dimensions of the relationship between knowledge and action. How then can research actively engage with alternative perspectives on how climate change, injustice and (conversely) climate justice are, and might be, experienced and practised? How should we attend to the stories and visions of different actors in urban governance, and identify practical pathways for action? How can the climate-just city move beyond theorizing to be made manifest?

To address this, the need for situated knowledge of the lives and livelihoods of those most marginalised - including issues of inter-species equity and the role of non-humans - has been highlighted (Roelvinck \& Gibson-Graham, 2010). This entails a different kind of imaginary that connects situated practice with utopian thinking. As John Friedmann (2008) outlines:

Utopian thinking has two moments that are inextricably joined: critique and constructive vision. The critique is of certain aspects of our present condition: injustice, oppression, ecological devastation to name just a few. . . If injustice is to be corrected ... . we will need the concrete imagery of utopian thinking to propose steps that would bring us a little closer to a more just world (p. 104).

Work by J.K. Gibson-Graham and Gerda Roelvink for example has sought to shift justice meta-narratives away from 'what is to be done' (the ought), which they argue is a form of paralysis, and instead focus on 'what is already being done' (the is): the progressive activities of existing communities. They advocate focusing on the diverse experiments already taking 
place that promote active citizenry and challenge dominant capitalist modes of production through four ethical coordinates: (i) commons (how a commons is produced and sustained); (ii) consumption (whether and how products and surplus are to be consumed); (iii) necessity (what is necessary to personal, social and ecological survival); and (iv) surplus (how surplus is appropriated from and distributed to humans and non-humans) (Gibson-Graham \& Roelvink 2010, p.17).

We join with them in seeing research around the climate-just city "as a process of learning involving a collective of human and more-than human actors - a process of cotransformation that re/constitutes the world" (Gibson-Graham \& Roelvink 2010, p.1). Community urban climate justice work already underway reflects stories and practices that will actively shape the future of cities to come (Chatterton 2010). The dialogue and actions of global organisations such as 350.org (named for the limit of $350 \mathrm{ppm}$ on carbon emissions necessary to keep the global warming under 2C) or the many local climate community groups and coalitions that have emerged in cities throughout the world illuminate how people come together to make connections between social and environmental justice and to enact meaningful solutions to climate change. 350. org, for example, is a global grassroots "social media" movement that utilises the Internet and networking sites such as Facebook to connect local climate actions with global politics. As such, they construct new commons in which new kinds of community can, through knowledge production and personal practice, redefine necessity, consumption and surplus. 350.org's most recent campaign "The Moving Planet" launched climate actions that promoted clean energy and transport such as cycling in 2000 events in 175 countries (www.350.org). Other community activities have included the convening of "Climate Camps" near coal mines and power stations; the formation of Climate Summits and Peoples' Policies on Climate Change; and the creation of youth climate coalitions and local climate action groups. 
Mobilising the conceptual frame offered in this paper, we can also see how local groups are working in places like the Illawarra District and the Hunter Valley in New South Wales to simultaneously seek cultural, institutional and ecological transformations for climate security. Redolent of the types of initiatives called for by Birkeland (2008) and Sarkissian et al. (2009), these community led initiatives include: community gardening to combat growing food insecurity and preserve agro-biodiversity; blocking coal trains from delivering their payload to coal-fired power stations as a form of protest and intervention; working in solidarity with indigenous groups to effect change thus building networks with traditionally marginalised groups; farmers joining with city-folk to try to block coal-seam gas projects; and trade unions joining with schools, community groups, environmental organisations and tertiary institutions to map out transitions to a low carbon economy (see Evans, 2008). These are precisely the sorts of interventions which must be fore-grounded in socially and environmentally just Australian climate change policies (Wiseman, 2007).

What these community actions, both global and local, suggest is that there is already active work underway that is engaging with the kind of relational thinking and foresight that we argue is missing from official planning and policy responses to climate change. Processes of social learning and interconnection underpin grassroots climate actions that actively seek to transform our dependence on fossil fuels in socially and ecologically just ways. Urban planning might be greatly enhanced by research into such community-driven initiatives, informed by its specific context and responsive to the stories and practices of its citizenry. To this end the climate-just city will involve changing the civic dialogue around planning praxis and enlarging the boundaries of dialogue and action "so that demands for equity are no longer marginalized as a first step towards reversing the current tendency that excludes [eco-]social justice from the aims of urban policy" (Fainstein, 2006, p.26). It will also require exploring and disseminating creative ways to embed the concept of climate justice into mainstream 
urban planning thinking and decision-making practice. Crucially the framework guides researchers to go further to engage in experimentation with alternative and new discourses, political, eco-social relations and forms of economic distribution, oriented to a red-green ethic of equitable access to and relations with the natural world.

\section{Conclusion}

Climate change is now manifest in cities. If justice, as Low and Gleeson (1998, p.1) assert, "is no mere abstraction", then addressing the intertwined plight of both the planet and the poor must be at the heart of any progressive planning agenda. In this paper we have argued that the imperative of climate change adds urgency to the longstanding equity agenda in cities and urban areas, yet at the same time exacerbates that agenda's increasing marginalisation within contemporary planning debates and discourses. To this end we offer a conceptual/analytical frame for praxis - the climate-just city.

This is an agenda that advances the 'right to the city' discourse to combine environmental, ecological and social justice and their reciprocal flow of ideas and materialities. This involves moving beyond the techno-expert fix towards discursive and cultural change within a civil society that places justice front and the centre in urban planning activity (alternative or mainstream; formal or informal). Such an agenda includes a deliberate focus on: 'who dominates?' 'who benefits?', and 'who gets left behind?' and how the resultant priorities then become manifest eco-socio-spatially. More specifically this entails a focus on:

- What is the climate-just city and what does this entail?

- How do the practices and stories of climate justice connect people with other elements of the natural world?

- What benefits or detriments might the climate-just city have for marginalised human and non-human communities within particular urban contexts? and

- How does the climate just city challenge, complement, or replace current rights and privileges? 
Ultimately climate justice is about both means and ends; eco-social movements and policy/planning processes that seek progressive ends. We advocate a climate-just city imaginary that prioritizes addressing the needs and issues of those most marginalised (both human and non-human). As we have outlined, there is currently a paucity of conceptual or analytical frameworks that emphasise climate justice concepts in ways that move beyond the 'right to the city' discourse. Adopting an eco-cultural-political approach through the framework outlined above helps to keep sight of the complex lived, spatial and material dimensions of urban injustice and fosters a climate-just city imaginary for our times: one that is able to offer both critique and a constructive vision that supports and promotes more equitable urban environments of progressive possibility. Surely, this is the contemporary local/global urban opportunity that climate change offers us.

Acknowledgements: The authors would like to thanks the two anonymous reviewers for their constructive comments.

\section{References}

Adger, J. Paavola, S. Huq., \& M. Mace (Eds.) (2006) Fairness to adaptation to climate change. (Cambridge: Massachachusetts Institute of Technology).

Barnett, J. (2006) Climate change, insecurity and injustice, in W. Adger, J. Paavola, S. Huq., \& M. Mace (Eds.) Fairness to adaptation to climate change. (Cambridge: Massachachusetts Institute of Technology).

Baxter, B. (2005). A theory of ecological justice. (London: Routledge)

Bell, D. (2010). Ethics, justice and climate change. Environmental Politics. 19(3): pp.475-79.

Best, J. \& Paterson, M. (eds.) (2009). Cultural Political Economy. (New York, Routledge).

Bicknell, J., Dodman, D., \& Satterthwaite, D (Eds.) (2009) Adapting Cities to Climate Change: Understanding and Addressing the Development Challenges, (Sterling: Earthscan). 
Birkeland, J., (2008). Positive Development: From Vicious Circles to Virtuous Cycles Through Built Environment Design, (London: Earthscan).

Brotherhood of St Laurence, (2007). Equity in Response to Climate Change. Melbourne.

Byrne, J., Gleeson, B., Howes, M. \& Steele, W. (2009). Climate change and Australian urban resilience: the limits of ecological modernization as an adaptive strategy', in Davoudi, S., Crawford, J. \& Mehmood, A. (Eds.), pp. 136-54. Planning for Climate Change: Strategies for Mitigation and Adaptation for Spatial Planners. (London: Earthscan)

Byrne, J. (2010). Environmental justice. Encyclopedia of Geography. (Thousand Oaks: SAGE)

Byrne, J. (2011) The human relationship with nature: rights of animals and plants in the urban context, in Douglas, I., Goode, D., Houck, M.C. and Wang, R. (Eds.) The Routledge Handbook of Urban Ecology (London: Routledge)

Campbell, H, (2010) P. Marcuse et al. Searching for the Just City. Planning Theory and Practice, 11(2).

Campbell, S., \& Fainstein, S. (2005). Readings in Planning Theory. (Oxford: Blackwell Publishers)

Chatterton, P. (2010) The Urban Impossible: A Eulogy for the Unfinished City. City 14(3): pp. 234-244.

Clark, N. (2010). Volatile worlds, vulnerable bodies. Theory, Culture \& Society 27: pp.31-53.

Cutter, S. (2006) Vulnerability to Environmental Hazards in Cutter S L (ds) Hazards, Vulnerability and Environmental Justice, (London:Eathscan)

Dear, M., and Wolch, J. (1987). Landscapes of Despair: From Deinstitutionalization to Homelessness. (Princeton: University Press).

Demeritt, D. (2001). The construction of global warming and the politics of science.

Annals of the Association of American Geographers 91(2): pp. 307-37.

Dodson J. \& Sipe N. (2008). Unsettling suburbia: The new landscape of oil and mortgage vulnerability in Australian cities, (Brisbane: Urban Research Program Griffith University).

Edwards, T., Ftize, J., \& Wiseman, J. (2009) Community well-being in a changing climate: challenges for the Australian community sector. Just Policy, 50: pp.80-86.

Eisenschitz, A. (2008) Town planning, planning theory and social reform, International Planning Studies, 13(2), pp. 133-149. 
Evans, G.R. (2008) Transformation from "carbon valley" to a "post-carbon society" in a climate change hotspot: the coalfields of the Hunter Valley, New South Wales, Australia, Ecology and Society, 13(1), pp. 39-59.

Fainstein, S. (1996) New directions in planning theory, in S. Campbell \& S. Fainstein (Eds.) Readings in Planning Theory, (Oxford: Blackwell Publishing).

Fainstein, S. (2006). Planning and the just city. Searching for the Just City conference, Columbia University, New York, April 29.

Fainstein, S. (2010) The Just City (Cornell: Cornell University Press).

Fincher, R.\& Saunders, P (2001) Creating Unequal Futures? Rethinking Poverty, Inequality and Disadvantage, (Sydney: Allen \& Unwin).

Fishman, R. (1996) Urban Utopias: Ebenezer Howard \& Le Corbusier', in Campbell S \& Fainstein S (Eds.) Readings in Planning Theory, (Oxford: Blackwell Publishers).

Friedmann, J. (1987) Planning in the public domain: from knowledge to action (New Jersey: Princeton University Press)

Friedmann, J. (2008) The Uses of Planning Theory: A Bibliographic Essay, Journal of Planning Education and Research, 28, pp.247-257.

Garnaut, R. (2009). 'Foreword: climate change as an equity issue', in Moss, J. (Ed.). Climate Change and Social Justice. (Melbourne, MUP).

Gleeson, B. (2010) Lifeboat Cities.(Sydney: UNSW Press)

Gunder, M. (2011) Fanstein. The Just City, Urban Policy and Research, 29(1), pp. 94-96.

Gurstein, P. \& Vilches, S. (2010) The just city for whom? Re-conceiving active citizenship for lone mothers in Canada Gender, Place \& Culture: A Journal of Feminist Geography. 17(4):pp. $421-436$.

Hall, P. (2002) Cities of Tomorrow: an intellectual history of urban planning and design in the twentieth century (Malden, Mass. Blackwell).

Harvey, D.(1989) The urban experience. (Oxford: Blackwell).

Harvey, D. (1996). Justice, Nature and the Geography of Difference. (Oxford, Blackwell).

Harvey, D. (2005) A brief history of neo-liberalism. (Oxford: Oxford University Press)

Haughton, G. (1999). Environmental justice and the sustainable city. Journal of Planning Education Research, 18:pp. 233 - 243.

Holifield, R., Porter, M. \& Walker, G. (2009),Introduction spaces of environmental justice: Frameworks for critical engagement. Antipode, 41: pp. 591-612.

Houston, D. (2008). Crisis and resilience: Cultural methodologies for environmental sustainability and justice. Continuum 22: pp. 179-90. 
Hulme, M. (2010) Cosmopolitan climates: hybridity, foresight and meaning, Theory, culture and society, 27(2):pp.267-276.

Irazabal, C. (2009) One Size Does Not Fit All: Land Markets and Property Rights for the Construction of the Just City, International Journal of Urban and Regional Research, 33(2); pp,558-562.

IPCC (2007). Impacts, Adaptation and Vulnerability. Intergovernmental Panel on Climate Change Working Group II Report. (N.Y, United Nations).

Jessop, B. (1995). Towards a Schumpeterian workfare regime in Britain? Reflections on regulation, governance, and welfare state, Environment and Planning A, 27(10), pp.1613-1626.

Jessop, B. (2007). State Power: A Strategic-relational Approach. (Cambridge, Polity Press).

Jessop, B. \& Oosterlynck, S. (2008). Cultural political economy: On making the cultural turn without falling into soft economic sociology. Geoforum 39:pp. 1155-69.

Keil, R. (2003). Urban political ecology: progress report. Urban Geography 26:pp.640-51.

Kenny, M. \& Meadowcroft, J. (1997) Planning sustainability, (London, Routledge).

Koresawa, A., Konvitz, J. (2001) Towards a new role for spatial planning. In: OECD Towards a new role for spatial planning. (Paris: OECD).

Lefebvre H. (1996) Writings on cities. (Cambridge: Blackwell Publishing).

Low, N. \& Gleeson, B. (1998) Justice, Society and Nature: An Exploration of Political Ecology (London: Routledge).

Lovering, J. \& Turkman, H. (2011) Bulldozer Neo-liberalism in Istanbul: The State-led Construction of Property Markets, and the Displacement of the Urban Poor, International Planning Studies, 16(1), pp.73-96.

MacCallum, D. \& Byrne, J. (2009) (Ignoring) alternative discourses in local climate change policy: A South East Queensland Study. State of Australian Cities conference. Perth, 24-27 November.

Marcuse, P., Connelly, J., Novy, J., Olivo, I., Potter, C. \& Steil, J. (eds.) (2009) Searching for the Just City: Debates in Urban Theory and Practice, (London: Routledge).

McManus, P. (2005) Vortex cities to sustainable cities: Australia's urban challenge. (Sydney: University of New South Wales Press).

Miraftab, F. (2004) Making neo-liberal governance: the disempowering work of empowerment, International Planning Studies, 9(4), pp.239-259.

Moore, D. S., Pandian, A. \& Kosek, J. (2003). Introduction: The cultural politics of race and 
nature: terrains of power and practice, in Moore, D. S., Kosek, J. \& Pandian, A. (eds.), Race, Nature and the Politics of Difference. (Durham, Duke Uni Press: pp.1-69).

Morphet, J., Tewdwr-Jones, M., Gallent, N., Hall, B., Spry., M \& Howard, R. (2007) Shaping and Delivering Tomorrow's Places: Effective Practice in Spatial Planning, (London: RTPI, London).

Nicholson, T. (2007) Equity in response to climate change roundtable, (Melbourne, Brotherhood of St Lawrence).

Nussbaum, M (2000) Women and Human Development. (New York: Cambridge University Press)

O'Brien, P., and Robin Leichenko. (2000). Double exposure: assessing the impacts of climate change within the context of economic globalization. Global Environmental Change 10 (3):pp. 221-232.

Parsons, K. \& Shyler, D. (2003) From garden city to green city: the legacy of Ebenezer Howard, (Maryland: John Hopkins University Press)

Peel, M. (1995) The Urban Debate: From Los Angeles to the Urban Village, in Troy, P. (ed.) Australian Cities: Issues, Strategies and Policies for Urban Australia in the 1990's, pp. 39-65, (Melbourne: Cambridge University Press)

Pulido, Laura (2000) Rethinking Environmental Racism: White Privilege and Urban Development in Southern California. Annals of the Association of American Geographers 90(1): pp. 12-40.

Purcell, M (2002) Excavating Lefebvre: The right to the city and its urban politics of the inhabitant, Geojournal, 58: pp.99-108.

Rawls, J. (1999) A theory of justice (Cambridge: Bellnap Press).

Ribera-Fumez, R. (2009). From Urban Political Economy to Cultural Political Economy: rethinking culture and economy in and beyond the urban. Progress in Human Geography 33:pp. 447-65.

Roelvink, G. \& Gibson-Graham, J.K.(2010) An Economic Ethics for the Anthropocene, Antipode, 41(1): pp.320-346.

Sandercock, L. (1990) Property, politics and urban planning: A history of Australian city planning 1890-1990 (New Jersey: Transaction Publishers).

Sarkissian, W., Hofer, N., Shore, Y., Vajda, S. and Wilkinson, C. (2009) Kitchen Table Sustainability: Practical Recipes for Community Engagement with Sustainability (London: Earthscan).

Sen, A. (1999) Sen, Amartya, Development as Freedom, (Oxford, Oxford University Press) 
Steele, W. \& Gleeson, B. (2010). Mind the governance gap: oil vulnerability and urban resilience in Australian cities. Australian Planner,47: pp. 302-10.

Steele, W. \& Gleeson, B. (2011). The great risk shift: the securitization of Australian housing. Housing Studies. 26 (2):pp. 235-250.

Stilwell, F. (2000). Changing Track: A New Political Economic Direction for Australia.(Annandale: Pluto Press).

Stretton, H. (1989) Ideas for Australian Cities (Sydney: Transit Publishing)

Swyngedouw, E. \& Heynen, N. (2003). Urban political ecology, justice and the politics of scale. Antipode. 35: pp.898-918.

UN (2011) Cities and Climate Change: Policy directions. Global Report on Human Settlements 2011.United Nations Human Settlements Program. (London: Earthscan).

Waitt, G., Head, L., \& Gill, N. (2006) Introduction: applied natures: cultural engagements with Australian environmental management. Australian Geographer 37:pp.1-3.

Winkler, T. (2009) For the equitable city yet to come, Planning Theory and Practice, 10(1), pp.65-83.

Wiseman, J. (2007) Climate change and social justice: towards an Australian research and policy development agenda, Just Policy, 46, pp. 8-11.

Wolch, J. (2002). Anima urbis. Progress in Human Geography, 26, pp.721-74

Young, I.M. (1990) Justice and the Politics of Difference (Princeton University Press, 1990) 